\title{
Profit Distribution Management and Islamic Banks' Market Power in Indonesia
}

\author{
Tastaftiyan Risfandy* \\ Faculty of Economics and Business Universitas Sebelas Maret, Indonesia
}

\begin{abstract}
Operating in the competitive dual banking market, Islamic banks' behavior often mimics conventional banks. One of the ways to do this is by managing their earnings so that their deposit rate of return could be closely pegged to the conventional banks' deposit interest rate. Farook et al. (2012) define this term as "profit distribution management" or PDM. This paper investigates whether PDM practice in Islamic banks is affected by their market power. Using a sample of Islamic banks from 2009 to 2013 from Indonesia, the most populous Muslim country adopting dual banking market, we find that bank with a high market power are less engage in PDM. This means that, when Islamic banks are able to set high price of their banking product in the competitive market, they are already reach specific market position. In this case, Islamic banks is observed manage their earnings but in the lower intensity. We also provide empirical evidence that other factors such as governance structure and market share of Islamic banks are also matter for the PDM. Some policy implications are discussed.
\end{abstract}

Keywords: Profit distribution management, market power, Islamic banks, governance.

\section{Background}

Recent studies in Islamic banks raise more doubt on how Islamic banks operate, especially in the Islamic rule and spirit applied by the banks. Previously expected as "interest-free" banks, Islamic banks nowadays cannot fulfill its expectations. Even though many Islamic advocates argue that PLS principle can ensure bank to operate more efficiently and promoting equality and justice, after three decades of Islamic banks, Islamic banks are seemed to deviate still from the theoretical principles of Islamic banks (Khan, 2010). Until this moment, Islamic banks only allocate a small portion of their fund for lending using PLS contract (musyarakah or mudharabah contract). Most contracts used by Islamic banks are murabahah (mark-up price contract) and ijarah (leasing contract). On the other words, Islamic banks cannot apply the spirit of PLS as in the reason they exist.

Islamic banks are also rarely set their deposit rates based on bank profitability as suggested by PLS principle. Islamic deposits is empirically proven by Chong and Liu (2009) being closely pegged to conventional deposits. Islamic banks employ what it called "depositor profit distribution management" or PDM, defined as Islamic banks discretion to pay deposit rates based on market rates (interest rates) and away from assets return (Farook et al., 2012). Islamic banks perform PDM by establishing reserves to make sure when Islamic banks do not have sufficient profit allocated for their depositors; they will take some fund from reserves. Conversely, at the moment when Islamic banks are able to generate huge profit, they will store the fund in the reserves after depositor allocation. By doing this way, Islamic banks can pay depositor rate of return as market interest rates. By using PDM, they are able to compete with other banks, especially with conventional banks because they are in the similar banking

${ }^{*}$ Corresponding author at Jl. Ir Sutami No.36 A, Pucangsawit, Kec. Jebres, Kota Surakarta, Jawa Tengah 57126. Email: tastaftiyan.risfandy@staff.uns.ac.id 
environment. PDM can make Islamic banks able to pay "interest-like" deposit rate, which is very efficient for attracting customers to make Islamic deposits.

In this study, we attempt to investigate PDM practice in the case of Indonesian Islamic banks. We choose Indonesia as our country sample based on several reasons. First, Indonesia is one of the countries that being the center of Islamic banking development in the world, especially in East Asia. Ernst and Young (2015) report that US\$ 625 billion or 80\% of Islamic banking assets in the world are in QISMUT (Qatar, Indonesia, Saudi Arabia, Malaysia, UAE, and Turkey). Second, Islamic banks that engage in PDM are supposed to be happened only in the country using dual banking system such as Indonesia. With the market share less than $10 \%$, Islamic banks in Indonesia is supposed to employ PDM in the higher extent rather than other countries with lower Islamic banks market share.

The main issue we want to observe in this study is the nexus between PDM and banks market power. We propose a negative association between PDM and bank market power as a bank with high market power do not need to employ PDM anymore. PDM is used particularly by the bank in the early stage of developing. When they already have great market power in the market, PDM is no longer needed.

The position where Islamic banks are less engage in PDM can also be captured by market share of the bank. Islamic banks that have high market share are supposed to have high profitability compared to the bank with low market share. This kind of bank has an enormous number of loyal depositors with huge deposits. They are enjoy putting their money in the bank because the larger bank is usually offering better features, greater return, and lower risk. Thus, the negative association between bank market share and PDM is also expected.

Another issue we build in this paper is about Islamic bank governance. The relationship between governance and PDM practice in Islamic banks is still become the question that should be investigated deeply. Different to conventional banks, Islamic banks do not have an only board of directors (BOD) as part of the banks ensuring good corporate governance but also sharia supervisory board (SSB). While BOD monitors managers to manage banks in order to maximize shareholder value, SSB has a role in monitoring sharia application in the banks. SSB takes responsibility that each transaction in Islamic banks complies with Islamic principle.

To our knowledge, a study about governance in Islamic banks is very limited. Most of them examining the impact of corporate governance on profitability (for instance, the most recent paper written by Mollah and Zaman, (2015). Other study reviews issues and option for ensuring sharia compliance for Islamic banks. Thus, this study will contribute to the literature by giving evidence about the impact of BOD and SSB on the extent of PDM in Islamic banks. We hypothesize that BOD positively impacts PDM. As representatives of shareholders, BOD has a duty to make sure that each manager of Islamic banks and the staff work well to get more deposits. BOD of Islamic banks may believe that using more extent of PDM can increase more depositors, more funding to be allocated for lending, and thus more profitability can be created from banking operation. Hence, the higher shareholder monitoring in the bank activity, the more extent of PDM.

Regarding SSB, we predict that sharia supervisory board (SSB) have a negative influence on PDM activity in Islamic banks. Since the function of SSB in the Islamic banks is to ensure that Islamic banks operates based on Islamic principle and do not pass the Sharia limitation (Mallin et al., 2015), SSB will attempt not to engage in PDM. Even though PDM is not prohibited by modern Sharia law, classical Sharia law may still question about it because, in PLS principle, depositor return has to be based on banks asset return. Furthermore, the higher influence of SSB in Islamic banks is associated with the lower extent of PDM.

In this paper, our analysis will go further by examining interaction impact between sets of our variables of interests. First, previously we expect a positive association between BOD and PDM while SSB is expected influence PDM negatively. Since governance rule in Islamic banks is held by both BOD and SSB, different influence between them may impact on the level of PDM engaged by the bank. More specifically, the extent of PDM will be influenced by the interaction between BOD and SSB. BOD depends on SSB and vice versa. For instance, the impact of BOD can be higher when the involvement of SSB is low, which lead to a higher extent of PDM.

Second, we expect that the impact of SSB and BOD will depend on the level of bank market share. The effects of SSB on PDM will be higher in the bank with lower higher market share because SSB can impose management to use the great extent of PDM only in the bank having high market share. SSB is 
less able to compel management when the bank has low market share. SSB have to understand that in order to win the competition and attracts more fund from depositors, Islamic bank has no choice rather than engaging in PDM. The association between BOD and SSB will be also depend on the bank market power. BOD can have more influence for bank, compelling bank to engage in PDM, if only the bank has considerable market power, and vice versa.

\section{Method}

\subsection{Econometrics modelling}

To analyze the impact of bank market power and governance on the extent of profit distribution management engaged by Islamic banks, we make the equation as follows.

$P D M_{i t}=\alpha_{1} L_{E R N E R i t}+\alpha_{2} B_{O D} D_{i t}+\alpha_{2} S S B_{i t}+\alpha_{3} M S_{i t}+\varphi X+\varepsilon i t$

Where $i$ and $t$ represent bank and year index, respectively. PDM is the extent of profit distribution management. Referring to Farook et al. (2012), there is four proxies to measure PDM: (1) assets spread, (2) deposit spread, (3) equity spread, (4) combined spread. Asset spread is spread between ROA (return on assets) and ROD (return on deposits). The concept of PLS state that return obtained by depositors should be derived from banks return (ROA). Higher bank return lead to higher depositor return and vice versa. At this point, higher spread between ROA and ROA indicate the higher extent of PDM because the value of ROA in Islamic banks should be near to ROA. Deposit spread is spread between deposit rate set by regulator and deposit rate set by the bank (ROD). When the value of Islamic deposit rate is approaching regulated deposit rate, it means that Islamic deposit mimics conventional deposits, suggesting the higher extent of PDM. Equity spread is spread between ROE (return of equity) and ROD (return on deposits). Using similar arguments as in asset spread, higher spread suggest the higher extent of PDM. Lasts, equity spread, is multiplication product of asset spread and deposit spread. All of PDM measurement are in absolute value, because either the spread are positive or negative, it indicates the extent of PDM. The more positive indicate the more extent of PDM. Similar case in the negative value as well. In this paper, we will only use asset spread and equity spread due to the lack of data. We cannot find the data about monthly deposit rate in Indonesia. Bank Indonesia have BI-rate as regulatory interest rate, and it is published monthly. However, due to the invariability of BI-rate, we decide not to use that.

LERNER is Lerner index computed following the method of Fu et al. (2014). It is Lerner index calculated by two input cost function specification. Lerner index is the difference between the price of the product and marginal costs, divided by price. The value of the index will be between " 0 " and " 1 " with higher value indicates higher market power. We predict LERNER negatively impacts PDM because banks with high market power will less engage in PDM due to their superiority we explain previously.

BOD is our first governance variables. It measures the level of board involvement and monitoring in the bank, ensuring that managers and their staffs work to increase shareholder value. BOD is measured by the number of board of directors in the bank. The Greater number of BOD suggests higher involvement and monitoring. We hypothesize that BOD impacts positively on PDM because BOD may force the bank to engage in PDM in the higher extent, to get more depositors, more profitability, and then more shareholder return.

SSB is the second governance variable. Similar to BOD, SSB measure involvement and monitoring in the bank, regarding the application of Islamic value. SSB is measured by the number of shariah supervisory board, with the higher number of board indicate higher involvement and monitoring. We predict the negative association between SSB and PDM as higher SSB involvement and monitoring means higher sharia compliance, and SSB will advise to less engage in PDM practice.

MS is bank market share. One may argue that Islamic banks employ PDM to get more depositors, gain more profitability, and thus increase their market share. It means that when Islamic banks have a considerable market share in the banking market, they will less engage in PDM. Furthermore, a negative association is expected.

$\mathrm{X}$ is a vector of the bank-level control variables. We use three variables. First, we use a ratio of total loan to total assets (TLTA). This ratio captures asset structure of the bank, how many loans granted to investors by bank. The positive nexus between TLTA and PDM is expected because a bank with the higher loan may have higher return volatility. Bank need to engage in PDM to smooth their banking 
business return. Second, we use a ratio of total equity to total assets (TETA). This measurement are able to capture solvency risk. Bank with a higher amount of equity compared to their total assets means lower solvency. Lasts, we introduce natural logarithm of total assets (LNTA) as a measurement of bank size. We predict LNTA have a negative association with PDM as bigger bank are less willing to engage in PDM.

In this paper, we also predict that our governance variables, BOD and SSB, depend on each other. The impact of SSB will depend on BOD and vice versa. For instance, the effects of BOD can be higher when the involvement of SSB is low, which lead to a higher extent of PDM. The duality of board (SSB and BOD), even though each of them has their own role, conflict of interests may still happen. For instance, BOD is looking for shareholder value, which is derived from bank profitability. Since bank which use PDM is expected to have more depositors and thus more profitability, BOD will always recommend their managers to engage in PDM. However, SSB may suggest engaging less in PDM because it is less sharia compliance. PDM is somewhat inappropriate with PLS principle. To analyze this thing, we will make the interaction between BOD and SSB as follows.

$$
P D M_{i t}=\alpha_{1} L_{E R N E R i t}+\alpha_{2} B O D_{i t}+\alpha_{2} S S B_{i t}+\alpha_{3} M S_{i t}+\beta_{1} B O D^{*} S S B+\varphi X+\varepsilon i t
$$

A positive value in $\beta_{1}$ indicates that there is a significant difference in the impact of SSB and SSB when the involvement of SSB and BOD is high and low.

Previously we explain that PDM depends on market share (MS). Bank with higher market share will less engage PDM. We predict that our governance variables are also depend on bank market share. We employ other interaction, consist of the MS*BOD and MS*SSB.

$$
\begin{aligned}
& P D M_{i t}=\alpha_{1} \text { LERNER }_{i t}+\alpha_{2} \text { BOD }_{i t}+\alpha_{2} S S B_{i t}+\alpha_{3} M S_{i t}+\beta_{1} M S^{*} B O D+\varphi X+\varepsilon_{i t} \\
& P D M_{i t}=\alpha_{1} \text { LERNER }_{i t}+\alpha_{2} \text { BOD }_{i t}+\alpha_{2} S S B_{i t}+\alpha_{3} M S_{i t}+\beta_{1} M S^{*} S S B+\varphi X+\varepsilon_{i t}
\end{aligned}
$$

\subsection{Data, sample, and descriptive statistics}

We use monthly financial report of all Islamic banks 2009 to 2013. We do not use annual report because Islamic banks in Indonesia is still new. There will be very limited (insufficient) observation if we use annual reports. If we use monthly report, we will have more observations that lead to higher validity. All of the data are provided by Bank Indonesia and Otoritas Jasa Keuangan.

Currently, there is 11 full-fledged commercial Islamic bank in Indonesia. All of them is resulted from spin-off of their parents, except Bank Muamalat. On the other words, ten of them was born previously as Islamic windows and operate under conventional banks license. Descriptive statistics of those banks are displayed in table 1.

Surprisingly, Maybank is the bank with highest market power. This may because this bank is originated from Malaysia. Being in the one of the fastest developed countries regarding their Islamic banks, Maybank successfully implement what have they done in the origin country.

Bank Syariah Mandiri is the bank with a highest market share (40\%), followed by Bank Muamalat (30\%) and thus BRI Syariah (8\%). According to the theory of competition, especially market concentration, a banking market with more than $50 \%$ market share owned by three biggest banks is low competition market. The sum of all three biggest Islamic banks in Indonesia has been more than $70 \%$.

If we look at the "total" row, standard deviation of PDM variables is very low. Asset spread has only $0.7 \%$ while equity spread is $4 \%$. This indicates that Islamic bank in Indonesia also engages in PDM because the standard deviation of the bank who do not use PDM is supposed to be high.

\subsection{Model Estimator}

We use random effect model to estimate equation (1), (2), (3), and (4). Our choice of using random effect is because we have governance variable (SSB and BOD) which rarely changing over time. In our descriptive statistics, many of Islamic bank do not change the number of BOD or SSB, displayed by zero standard deviation. The use of random effect to deal with rarely changing variable is consistent to Plumper and Troeger (2007). However, for robustness tests, we will still provide estimation results using fixed effect model. 
Table 1. Descriptive statistics of the variables, displayed by the name of bank

\begin{tabular}{|c|c|c|c|c|c|c|c|c|c|c|c|}
\hline & Bank Name & Statistics & $\begin{array}{l}\text { Asset } \\
\text { spread }\end{array}$ & $\begin{array}{l}\text { Equity } \\
\text { Spread }\end{array}$ & Lerner & $\begin{array}{l}\text { Market } \\
\text { Share }\end{array}$ & BOD & SSB & Loan/TA & Equity/TA & TA \\
\hline \multirow{2}{*}{1} & & $\mathrm{Sd}$ & 0.004 & 0.031 & 0.080 & 0.002 & 0 & 0 & 0.169 & 0.073 & 586,820 \\
\hline & & $\operatorname{Max}$ & 0.026 & 0.220 & 0.583 & 0.019 & 3 & 2 & 0.723 & 0.402 & $2,995,070$ \\
\hline \multirow[t]{2}{*}{2} & BNI Syariah & Mean & 0.003 & 0.030 & 0.330 & 0.083 & 3.218 & 2 & 0.588 & 0.122 & $10,938,789$ \\
\hline & & $\mathrm{Sd}$ & 0.003 & 0.020 & 0.144 & 0.011 & 0.417 & 0 & 0.074 & 0.032 & $4,290,471$ \\
\hline \multirow[t]{4}{*}{3} & BRI Syariah & Mean & 0.005 & 0.029 & 0.246 & 0.089 & 4.686 & 2.314 & 0.453 & 0.128 & $10,373,349$ \\
\hline & & $\mathrm{Sd}$ & 0.006 & 0.019 & 0.148 & 0.018 & 0.468 & 0.468 & 0.255 & 0.056 & $5,679,545$ \\
\hline & & Min & 0.000 & 0.001 & 0.099 & 0.041 & 4 & 2 & 0.167 & 0.074 & $1,511,436$ \\
\hline & & $\operatorname{Max}$ & 0.034 & 0.085 & 0.684 & 0.141 & 5 & 3 & 0.826 & 0.297 & $20,356,863$ \\
\hline \multirow[t]{2}{*}{4} & Bank Jabar Banten & Mean & 0.004 & 0.013 & 0.363 & 0.023 & 4.786 & 3.214 & 0.663 & 0.229 & $2,977,411$ \\
\hline & & $\mathrm{Sd}$ & 0.003 & 0.011 & 0.088 & 0.004 & 0.414 & 0.414 & 0.111 & 0.061 & $1,229,041$ \\
\hline \multirow{3}{*}{5} & & $\mathrm{Sd}$ & 0.002 & 0.035 & 0.089 & 0.054 & 0.475 & 0 & 0.034 & 0.011 & $16,065,848$ \\
\hline & & Min & 0.000 & 0.001 & 0.012 & 0.252 & 5 & 3 & 0.616 & 0.057 & $13,147,466$ \\
\hline & & Max & 0.014 & 0.140 & 0.547 & 0.637 & 6 & 3 & 0.789 & 0.103 & $62,399,918$ \\
\hline \multirow[t]{4}{*}{6} & Bank Syariah Man & Mean & 0.004 & 0.070 & 0.289 & 0.417 & 6 & 3 & 0.683 & 0.073 & $43,418,843$ \\
\hline & & $\mathrm{Sd}$ & 0.002 & 0.046 & 0.059 & 0.056 & 0 & 0 & 0.026 & 0.006 & $16,846,769$ \\
\hline & & Min & 0.000 & 0.004 & 0.180 & 0.334 & 6 & 3 & 0.603 & 0.060 & $17,157,081$ \\
\hline & & Max & 0.009 & 0.160 & 0.417 & 0.698 & 6 & 3 & 0.733 & 0.081 & $66,942,422$ \\
\hline \multirow[t]{3}{*}{7} & Bukopin Syariah & Mean & 0.008 & 0.022 & 0.208 & 0.029 & 4 & 2.667 & 0.703 & 0.086 & $2,984,365$ \\
\hline & & $\mathrm{Sd}$ & 0.007 & 0.022 & 0.185 & 0.010 & 0 & 0.475 & 0.077 & 0.029 & $1,144,383$ \\
\hline & & Min & 0.000 & 0.001 & -0.511 & 0.018 & 4 & 2 & 0.312 & 0.064 & 677,449 \\
\hline
\end{tabular}




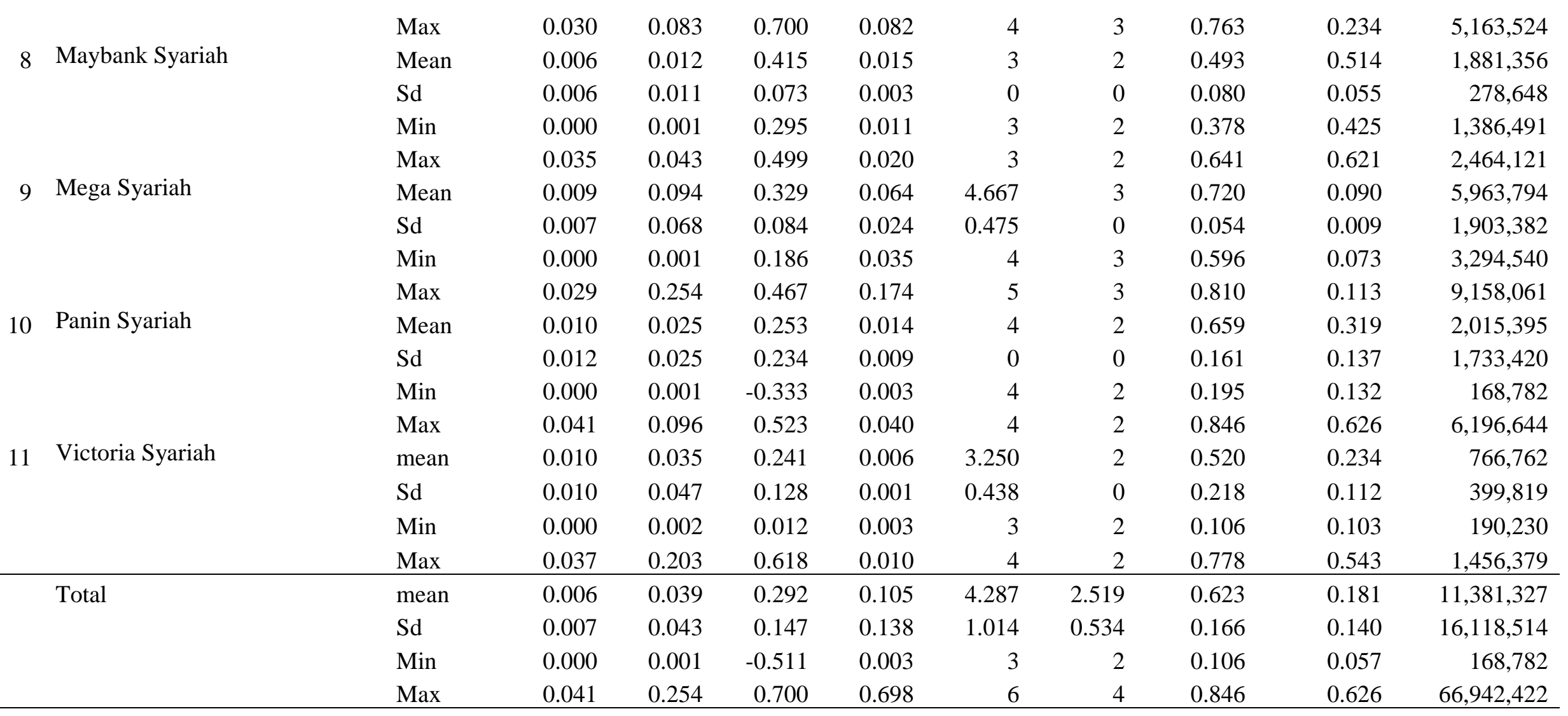




\section{Results}

\subsection{Random effect model}

As explained previously, we use random effect because our governance variables are rarely changing-over-time. This is also consistent with the explanation by Plumper and Troeger (2007). We regress PDM on Lerner index, sharia supervisory boards, board of directors, and sets of control variables. Our results are displayed in table 2.

Consistent to our expectation, we find a positive association between LERNER and PDM. LERNER negatively influence PDM, either using assets spread or equity spread proxies. The results is robust across 8 estimation. This result implies that higher market power of the Islamic bank will lead to lower extent of PDM. Bank with higher market power means competitive banks. Since those banks are already competitive, they are less engage in PDM.

The results of MS coefficient is mixed, it is negative in estimations 1,2,3, and 8 but positive in the estimations 3 and 7. As the overall results show negative association, we may say that the higher market share of Islamic banks, the lower extent of PDM will be. Bank with higher market share are less willing to engage in PDM as they are already 'superior'.

We find that BOD positively impacts PDM. Higher BOD involvement in the bank daily operation will recommend their bank managers to engage in the higher extent of PDM. As the rule of BOD is to ensure managers for making more profitability, they will always suggest to perform PDM. On the other hand, we find that SSB positively influence BOD. This is contrary with our expectation that the nexus between SSB and PDM is negative because SSB ensure sharia compliance in the bank. When SSB recommend to more engage in PDM, it means that SSB does not mind if the bank 'somewhat deviates' from its Islamic principle.

The possible explanation why SSB positively influence PDM is because SSB itself is appointed by BOD. Furthermore, people who sit in bank SSB is basically have political connection with BOD. BOD will always choose sharia board which is consistent with their company goal and expectation. To confirm for this possibilities, we have been make interaction between BOD and SSB. Negative coefficient displayed by BOD*SSB suggest that higher extent of SSB involvement will decrease the extent of PDM, as in our expectation. However, we do not find significant results wither in asset spread or equity spread proxies.

Regarding our other interaction variables, first, we find that the impact of BOD on PDM depend on the level of market share that Islamic bank have. Higher market share will decrease the impact of BOD, confirming our expectation that BOD will less recommends their bank to engage in PDM when the bank already have high market share. Second, we find negative coefficient on the interaction of MS*SSB, particularly in equity spread proxy. This evidence suggest that higher bank market share is associated with higher extent of PDM. This result is somewhat contrary with our results in MS*BOD interaction variable. SSB may thinking that higher market share means lower risk, and thus Islamic bank can engage in PDM (engaging in PDM means more risk-taking).

Turn to our control variables, first, we do not find any significant association between TLTA and PDM. This suggests that bank asset structure does not have a relationship with the extent of PDM engaged by Islamic banks. Second, we find a positive association between TETA and PDM, especially in asset spread proxy, suggesting that lower insolvency risk leads to higher PDM practice. Bank with less risk is brave enough to engage in PDM, consistent with our expectation. Third, our result displays that, in asset spread proxy, LNTA negatively influences PDM. This confirms our previous expectation that bigger banks will less engage in PDM because they are already big, so even not using PDM is not a problem for them.

\subsection{Robustness: fixed effect model}

We perform robustness test using fixed effect to confirm our random effect results. The result is displayed in table 3. In overall, we do not find any significant differences in the fixed effect estimators, compared to random effect estimator. Even in this model we can confirm the existence of a political connection between BOD and SSB, by the negative coefficient in BOD*SSB. It suggests that the impact of BOD on PDM decrease with the increase of SSB influence. 
Table 2. Estimation results using random effect estimator

\begin{tabular}{|c|c|c|c|c|c|c|c|c|}
\hline & \multicolumn{4}{|l|}{ Assets Spread } & \multicolumn{4}{|c|}{ Equity Spread } \\
\hline & (1) & (2) & (3) & (4) & $(5)$ & $(6)$ & (7) & $(8)$ \\
\hline LERNER & $\begin{array}{l}-0.0115 * * * \\
(-5.71)\end{array}$ & $\begin{array}{l}-0.0107 * * * \\
(-5.21)\end{array}$ & $\begin{array}{l}-0.0108 * * * \\
(-5.36)\end{array}$ & $\begin{array}{l}-0.0116 * * * \\
(-5.74)\end{array}$ & $\begin{array}{l}-0.0346 * * * \\
(-2.75)\end{array}$ & $\begin{array}{l}-0.0332 * * * \\
(-2.58)\end{array}$ & $\begin{array}{l}-0.0293 * * \\
(-2.35)\end{array}$ & $\begin{array}{l}-0.0366^{* * *} \\
(-2.91)\end{array}$ \\
\hline MS & $\begin{array}{l}-0.00939 * \\
(-1.72)\end{array}$ & $\begin{array}{l}-0.00994^{*} \\
(-1.71)\end{array}$ & $\begin{array}{l}0.0719 * * \\
(2.40)\end{array}$ & $\begin{array}{l}-0.124 \\
(-1.46)\end{array}$ & $\begin{array}{l}0.0337 \\
(0.74)\end{array}$ & $\begin{array}{l}0.0387 \\
(0.81)\end{array}$ & $\begin{array}{l}0.811 * * * \\
(4.11)\end{array}$ & $\begin{array}{l}-1.365^{* * *} \\
(-2.21)\end{array}$ \\
\hline BOD & $\begin{array}{l}0.00268 * * * \\
(4.41)\end{array}$ & $\begin{array}{l}0.00770 * * \\
(2.45)\end{array}$ & $\begin{array}{l}0.00455^{* * * *} \\
(5.26)\end{array}$ & $\begin{array}{l}0.00305^{* * * *} \\
(4.77)\end{array}$ & $\begin{array}{l}0.0256^{* * * *} \\
(6.14)\end{array}$ & $\begin{array}{l}0.0370^{*} \\
(1.69)\end{array}$ & $\begin{array}{l}0.0429 * * * \\
(7.29)\end{array}$ & $\begin{array}{l}0.0293 * * * \\
(6.61)\end{array}$ \\
\hline SSB & $\begin{array}{l}0.00286 * * * \\
(3.43)\end{array}$ & $\begin{array}{l}0.0113 * * \\
(2.14)\end{array}$ & $\begin{array}{l}0.00299 * * * \\
(3.51)\end{array}$ & $\begin{array}{l}0.00148 \\
(1.00)\end{array}$ & $\begin{array}{l}0.0113 * * \\
(1.97)\end{array}$ & $\begin{array}{l}0.0301 \\
(0.82)\end{array}$ & $\begin{array}{l}0.0114 * * \\
(1.99)\end{array}$ & $\begin{array}{l}-0.00825 \\
(-0.79)\end{array}$ \\
\hline Lag TLTA & $\begin{array}{l}0.00125 \\
(0.66)\end{array}$ & $\begin{array}{l}0.00107 \\
(0.56)\end{array}$ & $\begin{array}{l}0.00143 \\
(0.76)\end{array}$ & $\begin{array}{l}-0.000143 \\
(-0.06)\end{array}$ & $\begin{array}{l}-0.00545 \\
(-0.45)\end{array}$ & $\begin{array}{l}-0.00601 \\
(-0.49)\end{array}$ & $\begin{array}{l}-0.00592 \\
(-0.50)\end{array}$ & $\begin{array}{l}-0.0233 \\
(-1.62)\end{array}$ \\
\hline Lag TETA & $\begin{array}{l}0.0183 * * * \\
(4.05)\end{array}$ & $\begin{array}{l}0.0210 * * * \\
(4.48)\end{array}$ & $\begin{array}{l}0.0219 * * * \\
(4.67)\end{array}$ & $\begin{array}{l}0.0191 * * * \\
(3.94)\end{array}$ & $\begin{array}{l}0.0452 \\
(1.42)\end{array}$ & $\begin{array}{l}0.0492 \\
(1.52)\end{array}$ & $\begin{array}{l}0.0503 \\
(1.58)\end{array}$ & $\begin{array}{l}0.0323 \\
(0.99)\end{array}$ \\
\hline Lag LNTA & $\begin{array}{l}-0.00181 * * * \\
(-3.42)\end{array}$ & $\begin{array}{l}-0.00180 * * * \\
(-3.31)\end{array}$ & $\begin{array}{l}-0.00203 * * * \\
(-3.66)\end{array}$ & $\begin{array}{l}-0.00138 * * \\
(-2.32)\end{array}$ & $\begin{array}{l}0.00240 \\
(0.65)\end{array}$ & $\begin{array}{l}0.00250 \\
(0.66)\end{array}$ & $\begin{array}{l}-0.00105 \\
(-0.27)\end{array}$ & $\begin{array}{l}0.00664 \\
(1.62)\end{array}$ \\
\hline BOD*SSB & & $\begin{array}{l}-0.00184 \\
(-1.58)\end{array}$ & & & & $\begin{array}{l}-0.00403 \\
(-0.50)\end{array}$ & & \\
\hline $\mathrm{MS} * \mathrm{BOD}$ & & & $\begin{array}{l}-0.0153 * * * \\
(-2.78)\end{array}$ & & & & $\begin{array}{l}-0.150 * * * \\
(-4.01)\end{array}$ & \\
\hline $\mathrm{MS} * \mathrm{SSB}$ & & & & $\begin{array}{l}0.0379 \\
(1.35)\end{array}$ & & & & $\begin{array}{l}0.474 * * \\
(2.28)\end{array}$ \\
\hline Constant & $\begin{array}{l}0.0154^{*} \\
(1.79)\end{array}$ & $\begin{array}{l}-0.00761 \\
(-0.50)\end{array}$ & $\begin{array}{l}0.00939 \\
(1.05)\end{array}$ & $\begin{array}{l}0.0120 \\
(1.34)\end{array}$ & $\begin{array}{l}-0.133 * * \\
(-2.04)\end{array}$ & $\begin{array}{l}-0.187 * \\
(-1.76)\end{array}$ & $\begin{array}{l}-0.155^{* *} \\
(-2.32)\end{array}$ & $\begin{array}{l}-0.145^{* *} \\
(-2.19)\end{array}$ \\
\hline $\mathrm{N}$ & 556 & 556 & 556 & 556 & 557 & 557 & 557 & 557 \\
\hline $\mathrm{R}_{2}$ within & 0.210 & 0.219 & 0.230 & 0.216 & 0.0917 & 0.0927 & 0.119 & 0.104 \\
\hline $\mathrm{R}_{2}$ overall & 0.167 & 0.152 & 0.137 & 0.159 & 0.166 & 0.163 & 0.145 & 0.178 \\
\hline
\end{tabular}

Note: ${ }^{*}, * *$, and $* * *$ denotes significance in $10 \%, 5 \%$, and $1 \%$ levels, respectively. 
Table 3. Robustness results using fixed effect estimator

\begin{tabular}{|c|c|c|c|c|c|c|c|c|}
\hline & \multicolumn{4}{|c|}{ Assets Spread } & \multicolumn{4}{|c|}{ Equity Spread } \\
\hline & (1) & (2) & (3) & (4) & (5) & (6) & (7) & (8) \\
\hline LERNER & $\begin{array}{l}-0.0108 * * * \\
(-5.41)\end{array}$ & $\begin{array}{l}-0.00997 * * * \\
(-4.88)\end{array}$ & $\begin{array}{l}-0.0102 * * * \\
(-5.12)\end{array}$ & $\begin{array}{l}-0.0111 * * * \\
(-5.55)\end{array}$ & $\begin{array}{l}-0.0339 * * * \\
(-2.68)\end{array}$ & $\begin{array}{l}-0.0325 * * \\
(-2.51)\end{array}$ & $\begin{array}{l}-0.0289 * * \\
(-2.30)\end{array}$ & $\begin{array}{l}-0.0364 * * * \\
(-2.89)\end{array}$ \\
\hline BOD & $\begin{array}{l}0.00355^{* * *} \\
(5.03)\end{array}$ & $\begin{array}{l}0.0107 * * * \\
(2.94)\end{array}$ & $\begin{array}{l}0.00584 * * * \\
(6.00)\end{array}$ & $\begin{array}{l}0.00416^{* * *} \\
(5.40)\end{array}$ & $\begin{array}{l}0.0281 * * * \\
(6.37)\end{array}$ & $\begin{array}{l}0.0406^{*} \\
(1.78)\end{array}$ & $\begin{array}{l}0.0452 * * * \\
(7.44)\end{array}$ & $\begin{array}{l}0.0337 * * * \\
(7.00)\end{array}$ \\
\hline Lag TLTA & $\begin{array}{l}0.00223 \\
(1.17)\end{array}$ & $\begin{array}{l}0.00167 \\
(0.86)\end{array}$ & $\begin{array}{l}0.00208 \\
(1.10)\end{array}$ & $\begin{array}{l}-0.000335 \\
(-0.14)\end{array}$ & $\begin{array}{l}-0.00425 \\
(-0.35)\end{array}$ & $\begin{array}{l}-0.00530 \\
(-0.43)\end{array}$ & $\begin{array}{l}-0.00549 \\
(-0.46)\end{array}$ & $\begin{array}{l}-0.0278^{*} \\
(-1.89)\end{array}$ \\
\hline Lag TETA & $\begin{array}{l}0.0319 * * * \\
(5.75)\end{array}$ & $\begin{array}{l}0.0312 * * * \\
(5.64)\end{array}$ & $\begin{array}{l}0.0314 * * * \\
(5.71)\end{array}$ & $\begin{array}{l}0.0301 * * * \\
(5.37)\end{array}$ & $\begin{array}{l}0.0627 * \\
(1.84)\end{array}$ & $\begin{array}{l}0.0615^{*} \\
(1.80)\end{array}$ & $\begin{array}{l}0.0578 * \\
(1.72)\end{array}$ & $\begin{array}{l}0.0473 \\
(1.38)\end{array}$ \\
\hline Lag LNTA & $\begin{array}{l}-0.000999 \\
(-1.60)\end{array}$ & $\begin{array}{l}-0.00127 * * \\
(-2.00)\end{array}$ & $\begin{array}{l}-0.00161^{* *} \\
(-2.50)\end{array}$ & $\begin{array}{l}-0.000353 \\
(-0.50)\end{array}$ & $\begin{array}{l}0.00442 \\
(1.11)\end{array}$ & $\begin{array}{l}0.00392 \\
(0.96)\end{array}$ & $\begin{array}{l}-0.000278 \\
(-0.07)\end{array}$ & $\begin{array}{l}0.0104 * * \\
(2.32)\end{array}$ \\
\hline MS*SSB & & & & $\begin{array}{l}0.0700^{*} \\
(1.95)\end{array}$ & & & & $\begin{array}{l}0.641 * * * \\
(2.81)\end{array}$ \\
\hline Constant & $\begin{array}{l}-0.00688 \\
(-0.60)\end{array}$ & $\begin{array}{l}-0.0335^{*} \\
(-1.91)\end{array}$ & $\begin{array}{l}-0.00656 \\
(-0.58)\end{array}$ & $\begin{array}{l}-0.00970 \\
(-0.84)\end{array}$ & $\begin{array}{l}-0.191 * * * \\
(-2.61)\end{array}$ & $\begin{array}{l}-0.237 * * \\
(-2.15)\end{array}$ & $\begin{array}{l}-0.186^{* *} \\
(-2.58)\end{array}$ & $\begin{array}{l}-0.218 * * * \\
(-2.97)\end{array}$ \\
\hline $\mathrm{N}$ & 556 & 556 & 556 & 556 & 557 & 557 & 557 & 557 \\
\hline R2_W & 0.219 & 0.225 & 0.235 & 0.225 & 0.0928 & 0.0934 & 0.119 & 0.106 \\
\hline R2_O & 0.0798 & 0.0940 & 0.0953 & 0.0514 & 0.166 & 0.164 & 0.150 & 0.175 \\
\hline
\end{tabular}

Note: *,**, and *** denotes significance in $10 \%, 5 \%$, and $1 \%$ levels, respectively 


\section{Conclusion}

This research attempts to answer the question about the relationship between the extent of profit distribution management (PDM) and Islamic bank market power (LERNER). We regress PDM on LERNER, jointly with other variables of interest such as SSB, BOD, MS, and bank level controls. This research mainly find that market power (MS) is negatively associated with the extent of PDM in Islamic banks. Bank with high market power will less engage in PDM because they are already superior in the market. Market share (MS), on the other hand, is negatively associated with the extent of PDM in Islamic banks. Bank with high market share is less willing to engage in PDM because they are already superior in the market. They have had considerable market share.

Board of Directors (BOD) has positive nexus with the extent of PDM in Islamic banks. Higher extent of BOD involvement is associated with the higher extent of PDM, because BOD will encourage managers to engage in PDM, to attract depositors, to give more lending, and then get more profit. Sharia Supervisory Board (SSB) has positive nexus with PDM. This is contrary with our expectation. The possible explanation on this results is because there is political connection between SSB and BOD. SSB is appointed by BOD, and BOD will appoint people who are in line with the company purpose.

In this research, we also find that the impact of BOD on PDM depends on the strength of SSB. The more SSB involvement, the less impact of BOD will happen. BOD will less encourage their managers to engage in PDM when SSB has high involvement and monitoring in the bank. The impact of BOD is depend on MS as well. Negative coefficient from interaction variable means that when the bank has considerable market share, they BOD will less encourage bank to engage in PDM because of bank superiority in the banking market The impact of SSB is depend on MS. Positive coefficient is found from the interaction variable. SSB may think that higher market share means lower risk, and thus Islamic bank can engage in PDM (engaging in PDM means more risk-taking).

\section{Acknowledgment}

This paper is part of a research project funded by Universitas Sebelas Maret through maintenance research group grant that obtained by the author in 2016.

\section{References}

Chong, B.S., Liu, M.-H., 2009. Islamic banking: Interest-free or interest-based? Pacific-Basin Financ. J. 17, $125^{-144 .}$ doi:10.1016/j.pacfin.2007.12.003

Ernst and Young, 2015. EY World Islamic banking competitiveness report 2014-15.

Farook, S., Hassan, M.K., Clinch, G., 2012. Profit distribution management by Islamic banks: An empirical investigation. Q. Rev. Econ. Financ. 52, 333-347. doi:10.1016/j.qref.2012.04.007

Fu, X., Lin, Y., Molyneux, P., 2014. Bank competition and financial stability in Asia Pacific. J. Bank. Financ. 38, 64-77. doi:10.1016/j.jbankfin.2013.09.012

Khan, F., 2010. How "Islamic" is Islamic Banking? J. Econ. Behav. Organ. 76, 805-820. doi:10.1016/j.jebo.2010.09.015

Mollah, S., Zaman, M., 2015. Shari'ah supervision, corporate governance and performance: Conventional vs. Islamic banks. J. Bank. Financ. 58, 418-435. doi:10.1016/j.jbankfin.2015.04.030

Plumper, T., Troeger, V.E., 2007. Efficient estimation of time-invariant and rarely changing variables in finite sample panel analyses with unit fixed effects. Polit. Anal. 15, 124-139. doi:10.1093/pan/mpmoo2 